Abstracta Iranica Iranica

Revue bibliographique pour le domaine irano-aryen

Volume 42-43 | 2021

Comptes rendus des publications de 2019-2020

\title{
Or Amir. "Islamic Learning on the Silk Roads: The Career of Jalāl al-Dīn al-Akhawī"
}

\section{Simon Berger}

\section{OpenEdition}

1 Journals

\section{Édition électronique}

URL : https://journals.openedition.org/abstractairanica/53824

DOI : 10.4000/abstractairanica.53824

ISSN : 1961-960X

Éditeur :

CNRS (UMR 7528 Mondes iraniens et indiens), Éditions de l'IFRI

Référence électronique

Simon Berger, "Or Amir. "Islamic Learning on the Silk Roads: The Career of Jalāl al-Dīn al-Akhawī" », Abstracta Iranica [En ligne], Volume 42-43 | 2021, document 37, mis en ligne le 30 décembre 2021, consulté le 21 décembre 2022. URL : http://journals.openedition.org/abstractairanica/53824; DOI : https://doi.org/10.4000/abstractairanica.53824

Ce document a été généré automatiquement le 21 décembre 2022.

Tous droits réservés 


\title{
Or Amir. "Islamic Learning on the Silk Roads: The Career of Jalāl al-Dīn al-Akhawī"
}

\author{
Simon Berger
}

\section{RÉFÉRENCE}

Or Amir. "Islamic Learning on the Silk Roads: The Career of Jalāl al-Dīn al-Akhawī" in M. Biran, J. Brack, F. Fiaschetti (eds.). Along the Silk Roads in Mongol Eurasia: Generals, Merchants and Intellectuals. Oakland: University of California Press, 2020, p. 290-314.

1 Partant de la biographie que lui consacre l'auteur égyptien de la fin du $\mathrm{XV}^{\mathrm{e}}$ siècle asSakhāwī dans deux de ses œuvres (ậ-Ḍaw' al-lāmi‘ li-ahl al-qarn at-tāsi' ; at-Tuhfa al-lațîfa fi ta'rïkh al-Madina ash-Sharîfa), l'A. retrace la vie de Jalāl al-Dīn al-Akhawī, qui, en 1341, quitta sa ville natale de Samarcande pour un voyage de vingt-cinq ans vers l'Ouest qui le conduisit jusqu'à Médine. Akhawī profita de la sûreté offerte par la domination de la Horde d'Or sur de vastes étendues pour emprunter les routes commerciales de l'Asie centrale occidentale à travers les steppes jusqu'à la mer Noire et la Méditerranée, qui étaient donc également des voies de circulation des hommes, en particulier des savants religieux, notamment hanafites. La biographie de ce savant apparaît ainsi comme un témoignage précieux de la vie religieuse et culturelle des ulusud jochide et chaghadaïde islamisés. 


\section{AUTEURS}

SIMON BERGER

Doctorant EHESS, CETOBAC, Paris 